Volume 5 Nomor 2, Agustus 2020, halaman 146-153

\title{
ANALISIS KELAYAKAN ISI DAN PENYAJIAN BUKU MATEMATIKA SMP KELAS 7 MATERI ALJABAR
}

\section{FEASIBILITY ANALYSIS OF THE CONTENT AND PRESENTATION OF THE MATHEMATICS BOOK OF CLASS 7 ALGEBRA}

\author{
Jajang Rahmatudin ${ }^{1}$, Rifqi Hidayat ${ }^{2}$ \\ 1,2Program Studi Pendidikan Matematika, FKIP Universitas Muhammadiyah Cirebon \\ Email: j.rahmatudin87@ gmail.com ${ }^{1)}$, rifqi.math@ @mail.com ${ }^{2)}$
}

\begin{abstract}
ABSTRAK
Buku ajar merupakan sumber atau bahan utama yang dijadikan reverensi oleh guru berkaiatan dengan informasi dan pengetahuan yang akan disampaikan kepada peserta didik. Informasi yang termuat dalam buku ajar haruslah kredibel dan layak dibaca oleh peserta didik. Kriteria kelayakan sebuah buku menurut Badan Standar Nasional Pendidikan (BSNP) ada 4 hal, yaitu kelayakan isi, bahasa, penyajian, dan kegrafikan. Tujuan penelitian ini untuk menganalisis kelayakan isi dan penyajian materi aljabar siswa SMP Kelas 7. Jenis penelitian ini adalah penelitian kualitatif dengan pendekatan analisis. Teknik pengumpulan datanya menggunakan metode dokumentasi dan analisis datanya yaitu analisis konten dengan cara menganalisa terhadap materi yang ada pada sebuah buku. Sumber utama yang digunakan dalam penelitian ini yakni buku matematika siswa SMP kelas VII semester 1 kurikulum 2013 revisi 2017 pada materi aljabar. Analisis data dimulai dengan membaca dan menelaah seluruh data yang ada pada buku, kemudian melakukan koding data, mengorganisir dan menyusun hasil koding, memaparkan data dan pembahasaan hasil penelitian serta menarik kesimpulan. Berdasarkan analisis diperoleh kesimpulan bahwa buku matematika siswa SMP kelas VII semeter 1 kurikulum 2013 revisi 2017 pada materi aljabar memenuhi unsur kelayakan isi dan penyajian. Namun ada beberapa hal yang masih perlu diperbaiki yaitu: penyajian fakta, penyajian konsep dan penyajian prosedur.
\end{abstract}

Kata kunci:Kelayakan Isi, Kelayakan Penyajian, Aljabar.

\begin{abstract}
Textbooks are the main source or material that is used as a reference by the teacher regarding the information and knowledge that will be conveyed to students. The information contained in textbooks must be credible and worthy of being read by students. According to the National Education Standards Agency (BSNP) there are 4 eligibility criteria for a book, namely the feasibility of content, language, presentation, and graphics. The purpose of this study was to analyze the appropriateness of the content and presentation of the algebraic material for grade 7 junior high school students. This type of research is qualitative research with an analytical approach. The data collection technique uses the documentation method and the data analysis is content analysis by
\end{abstract}


analyzing the material in a book. The main source used in this research is the mathematics books of seventh grade junior high school students in semester 1 of the 2013 curriculum revision of 2017 on algebraic material. Data analysis begins with reading and analyzing all the data in the book, then coding the data, organizing and compiling the results of the coding, presenting the data and discussing the results of the research and drawing conclusions. Based on the analysis, it was concluded that the mathematics book of grade VII grade 1 students of the 2013 revision of the 2017 curriculum on algebra fulfilled the elements of content and presentation feasibility. However, there are several things that still need to be improved, namely: presentation of facts, presentation of concepts and presentation of procedures.

Keywords: Content Feasibility, Presentation Feasibility, Algebra.

How to Cite: Rahmatudin, J., \& Hidayat, R. (2020). Analisis Kelayakan Isi dan Penyajian Buku Matematika Smp Kelas 7 Materi Aljabar. Mathline: Jurnal Matematika dan Pendidikan Matematika, Vol. 5 No. 2, 146-153.

DOI: https://doi.org/10.31943/mathline.v5i2.138

\section{PENDAHULUAN}

Proses pembelajaran hakikatnya adalah proses interaksi antara guru, siswa dan materi ajar. Ketiganya saling melengkapi satu dengan yang lainnya, jika salah satunya tidak ada maka tida terjadi balancing. Pada era diskrupsi ini, dimana peran teknologi sangat membantu dalam pembelajaran namun tidak dapat menggantikan peran guru. Proses pembelajaran tetaplah memerlukan guru, karena proses belajar bukan hanya sekedar transfer of knowladge namun lebih kepada human building sehingga terbentuklah manusiamanusia yang cerdas dan berbudi pekerti. Hubungan antar guru, siswa dan materi tersaji dalam segitiga berikut ini:

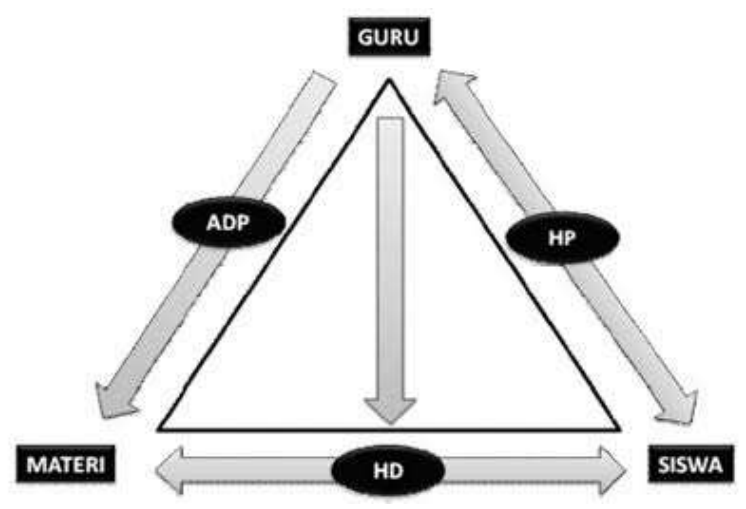

Gambar 1. Segitiga Didaktis yang Dimodifikasi (Suryadi, 2013)

Interaksi ketiganya amatlah penting demi terwujudnya tujuan pembelajaran itu sendiri. Fokus kajian yang dibahas dalam riset ini, hanya membahas tentang materi ajar. Materi pelajaran mengikuti pendekatan spiral, yang mana materi diajarkan dari hal konsepkonsep sederhana sampai konsep abtrak dan kompleks, materi yang diajarkan haruslah sesuai dengan tahap perkembangan peserta didik sehingga tidak terjadi hambatan belajar. Materi yang akan disampaikan oleh guru dikelas bisa dikatakan sebagai bahan ajar. Ada tiga prinsip dalam pemilihan bahan ajar, yaitu: (1) prinsip relevansi, (2) prinsip konsistensi, dan (3) prinsip kecukupan. Selain itu, ada empat hal yang harus diperhatikan dalam 
pemilihan bentuk bahan ajar, yaitu kebutuhan dan tingkat kemampuan awal para peserta didik yang menjadi sasaran pembelajaran, tempat dan keadaan dimana bahan ajar akan digunakan, metode penerapan dan penjelasannya, serta biaya proses dan produksi serta alat-alat yang akan digunakan untuk memproduksi bahan ajar (Prastowo, 2011: 58). Bahan ajar beragam macamnya, bisa berupa buku pelajaran, handout, modul, LAPD dan LKPD.

Buku teks pelajaran merupakan bagian terpenting dalam kurikulum 2013 karena memuat tujuan pembelajaran ataupun kompetensi yang diharapkan tercapai oleh peserta didik. Buku teks kurikulum 2013 perlu terus disempurnakan, baik buku guru maupun buku siswa karenapada penerapan kurikulum 2013, buku teks tersebut wajib digunakan sebagai acuan utama. Hal ini sejalan denganPeraturan Pemerintah Nomor 19 Tahun2005 tentang Standar Nasional Pendidikan bahwa buku teks pelajaran termasuk kedalam sarana pendidikan yang perlu diatur standar mutunya, sebagaimana jugastandar mutu pendidikan lainnya (Rizkianto dan Santoso, 2017: 230). Penggunaan buku ajar diatur melalui permen nomor 2 tahun 2008 dan permendikbud nomor 8 tahun 2016. Buku pelajaran terus dipebaiki oleh pemerintah mulai dari edisi 2013 sampai edisi revisi 2017. Kalau ditinjau dari segi efisiensi anggaran, tentu ini tidak efisien, karena akan membuat mubazir buku yang sebelumnya dan sekolah akan mengalokasikan dana $30 \%$ dari dana bantuan operasional sekolah (BOS) untuk mengadakan buku pelajaran. Buku pelajaran yang ada haruslah memuat standar isi sesuai permendikbud nomor 21 tahun 2016.

Buku teks pelajaran harus memuat unsur-unsur kulit buku, yakni kulit depan, kulit belakang, dan punggung buku. Selain itu harus memuat bagian-bagian buku yang meliputi bagian awal, bagian isi dan bagian akhir buku. Pada bagian isi suatu buku, perlu memeperhatikan aspek materi, aspek kebahasaan, aspek penyajian dan aspek kegrafikan (permendikbud, 2016). Mulyono (2007:21) menyatakan bahwa komponen utama buku teks pelajaran meliputi empat komponen, yaitu kelayakan isi, kebahsaan, penyajian dan kegrafikan. Salah satu buku teks pelajaran yang ada di sekolah adalah buku pelajaran matematika. Konten materi matematika sekolah yang diajarkan di tingkat menengah pertama meliputi 4 aspek, yaitu bilangan rasional, aljabar (pengenalan), geometri (termasuk transformasi), statistika dan peluang dan himpunan.

Rizkianto dan Santoso (2017; 234) menyampaikan bahwa terdapat kesalahankesalahan pada buku teks matematika kurikulum 2013 yang meliputi: a) kesalahan dan ketidaktepatan dalam penulisan kalimat, b) ketidak jelasan dalam menuliskan perintah soal, ketidaklengkapan dalam memaparkan materi atau contoh soal, c) kesalahan dalam perhitungan yang banyak ditemui pada contoh soal, d) kesalahan pada gambar atau ilustrasi, e) kesalahan konsep matematika, seperti menentukan gradien persamaan grafik garis lurus, grafik fungsi, letak titik pada koordinat kartesius, ukuran segitiga siku-siku, masalah nyata dalam kehidupan. Lebih lanjut Purwitasari (2016) Dalam proses analisis buku matematika kelas VII ditemukan tiga dari empat tipe kesalahan objek kajian matematika, yaitu: kesalahan yang berkaitan dengan fakta, operasi, dan konsep, sedangkan kesalahan yang berkaitan dengan prinsip tidak ditemukan.

Aljabar adalah salah satu kajian matematika yang akan terus dipelajari oleh peserta didik ketika mempelajari matematika (Ismunandar, 2019). NCTM (2010) Pembelajaran aljabar sebaiknya ditujukan untuk mengembangkan kemampuan siswa dalam: (1) memahami pola, relasi, dan fungsi; (2) merepresentasikan dan menganalisis situasi 
matematis menggunakan symbol dan prosedur aljabar; (3) menggunakan model matematika untuk menyatakan dan memahami relasi kuantitatif; dan (4) menganalisis perubahan dalam berbagai konteks yang bervariasi.

Kesalahan atau kesulitan belajar bisa menjadi sumber penting dalam pembelajaran. Wijaya (2016) Terdapat beberapa jenis kesulitan belajar aljabar yang dialami siswa, yaitu: (a) kesalahan dalam memahami lambang '='; (2) tendensi penggunaan prosedur aritmatika dan pengabaian variabel; (3) generalisasi; (4) abstraksi; dan (5) pemaknaan grafik. Hambatan belajar ini bisa menjadi acuan awal bagi guru dan penulis buku untuk merepresentasikan aljabar lebih baik lagi, sehingga pembelajaran lebih bermakna. Drijvers, dkk (2010) menyampaikan empat pandangan terkait pembelajaran aljabar, yaitu aljabar sebagai aktivitas manusia (algebra as human activity), aljabar sebagai aktivitas otak (algebra as brain activity), aljabar sebagai aktivitas personal (algebra as personal activity), dan aljabar sebagai aktivitas yang bermakna (algebra as meaningful activity).

Melihat pentingnya penguasaan materi aljabar oleh peserta didik di tingkat menengah pertama sebagai fondasi untk mempelajari materi aljabar di tingkat lanjut, maka perlu dilakukan kajian terhadap konten materi aljabar pada buku matematika siswa yang digunakan dalam kurikulum 2013 revisi 2017, maka peneliti mengangkat judul "Analisis kelayakan isi dan penyajian pada Buku Matematika Siswa SMP Kelas 7”. Adapun tujuan dari penelitian ini adalah untuk menganalisis kelayakan isi dan kelayakan penyajian materi aljabar pada buku matematika Siswa SMP Kelas 7 semester 1 kurikulum 2013 revisi 2017.

\section{METODOLOGI}

Penelitian ini dilakukan menggunakan metodelogi kualitatif dengan pendekatan noninteraktif yang disebut sebagai pendekatan analitis. Analsis data kualitatif bersifat induktif, yaitu suatu analisa berdasarkan pada data yang diperoleh yang selanjutnya dikembangkan pola hubungan tertentu. Peneliti menghimpun, mengidentifikasi, menganalisis dan mengadakan sistesis data, untuk kemudian mengadakan interpretasi terhadap konsep, kebijakan dan peristiwa yang secara langsung maupun tidak langsung diamati (Ghony dan Almanshur, 2012:65). Data diperoleh dari berbahai sumber yang relevan terutama buku ajar matematika SMP kelas VII edisi revisi 2017 yang menjadi buku pegangan di setiap sekolah. Subjek yang dikaji dalam penelitian ini adalah materi aljabar.

\section{HASIL DAN PEMBAHASAN}

Berdasarkan hasil analisis konten materi aljabar pada buku matematika siswa kelas VII semester I tahun 2013 revisi 2017, peneliti menemukan beberapa temuan diantaranya:

1) Penggunaan peta konsep yang belum mencakup keseluruhan materi. 


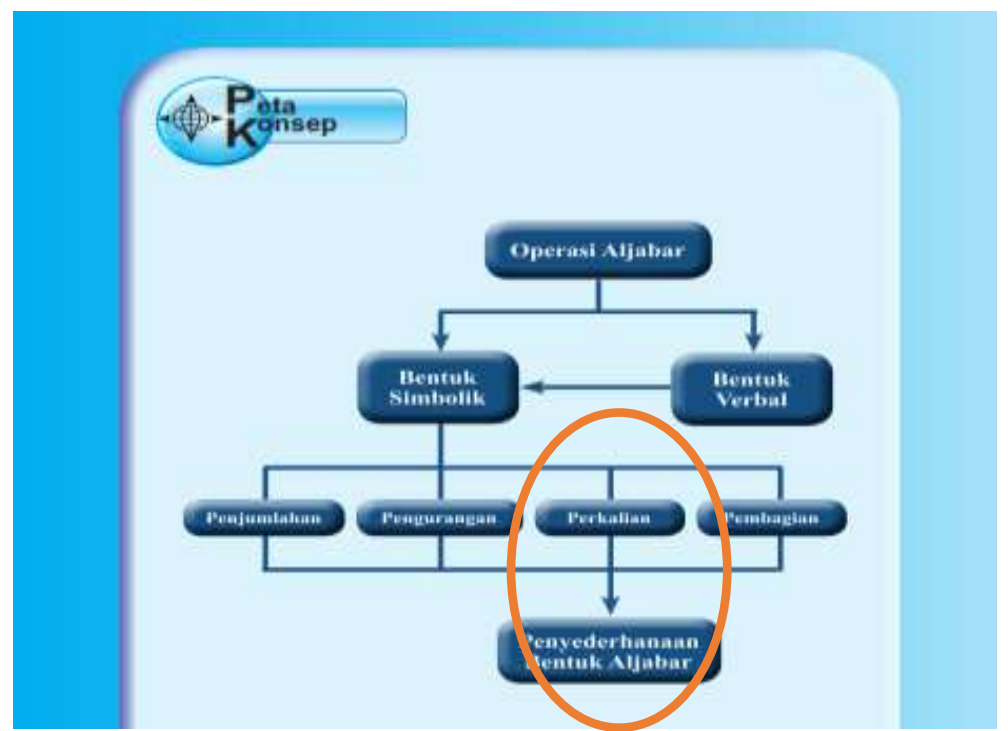

(Sumber : buku matematika siswa kelas VII semester I tahun 2013 revisi 2017 halaman 195)

Pada diagram diatas, peta konsep belum menggambarkan konten materi aljabar secara keseluruhan, pengenalan variabel, koefisien, konstanta, suku belum terjamah. Tanda panah yang mengarah ke bawah seharusnya tidak sejajar dengan kotak perkalian karena akan menimbulkan persepsi bahwa penyederhanaan bentuk aljabar hanya dioperasi perkalian. Selain itu juga, pemaparan tentang bentuk verbal dan simbolik belum diulas dalam buku.

2) Penggunaan simbol pada operasi perkalian bentuk aljabar

Secara umum hasil perkalian bentuk aljabar $(x+a) \times(x+b)$ mengikuti proses berikut.

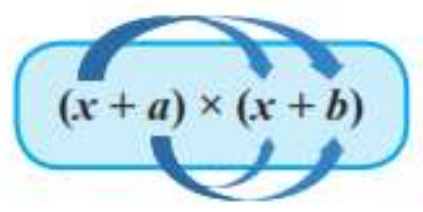

(Sumber : buku matematika siswa kelas VII semester I tahun 2013 revisi 2017 halaman 218)

Pada gambar diatas penggunaan anak panah akan membingungkan siswa, apa yang akan harus mereka kerjakan, sebaiknya pemberian panah diberikan langkah urutan pengoperasiannya misalkan dengan menggunakan angka. 
3) Penyajian soal yang membingungkan

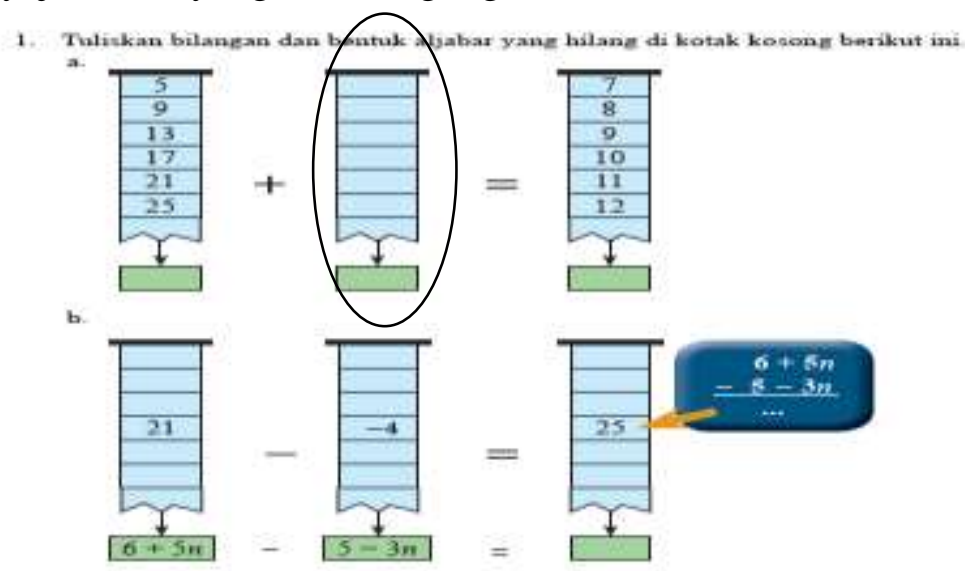

(Sumber : buku matematika siswa kelas VII semester I tahun 2013 revisi 2017 halaman 212)

Pada bagian a) kotak yang kosong akan membingungkan peserta didik untuk menerka jawaban sesuai dengan perintah yang dikehendaki. Alangkah baiknya jika penulis memberikan contoh satu bilangan atau bentuk aljabar pada kotak kosong bagian a.

4) Inkonsisten antara perintah yang ada pada soal dengan penyajian

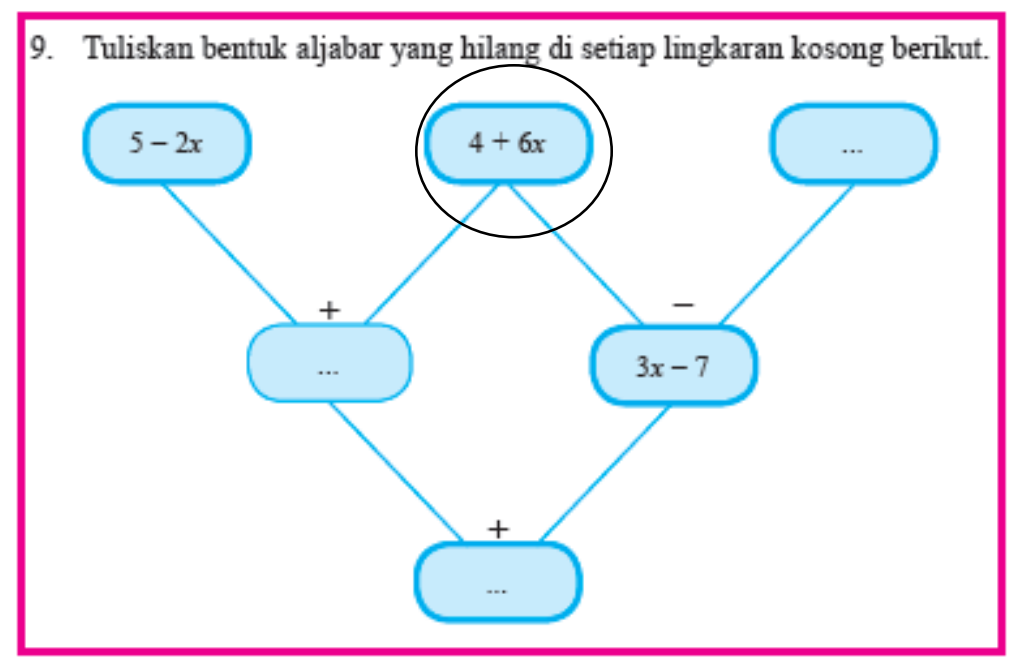

(Sumber : buku matematika siswa kelas VII semester I tahun 2013 revisi 2017 halaman 216)

pada perintah soal, siswa diminta menuliskan bentuk aljabar yang hilang pada setiap lingkaran kosong, padahal digambar bentuknya bukanlah lingkaran. Sebaiknya bentuk bulatan dirubah menjadi lingkaran, atau mengganti kata lingkaran nya.

5) Penyajian permasalahan dan alternatif penyelesaian masalah yang belum tepat. 


\section{Masalah 3.3}

Pak Idris mempunyai kebun apel berbentuk persegi dan Pak Tohir mempunyai kebun jeruk berbentuk persegi panjang. Ukuran panjang kebun jeruk Pak Tohir $20 \mathrm{~m}$ lebih dari panjang sisi kebun apel Pak Idris. Sedangkan lebarnya, $15 \mathrm{~m}$ kurang dari panjang sisi kebun apel Pak Idris. Jika diketahui kedua luas kebun Pak Idris dan Pak Tohir adalah sama, maka tentukan luas kebun apel Pak Idris?

(Sumber : buku matematika siswa kelas VII semester I tahun 2013 revisi 2017 halaman 217)

pada permasalahan 3.3 terlihat bahwa penulis menggunakan satuan meter untuk menunjukan selisih panjang sisi kebun pak tohir dan pak idris.

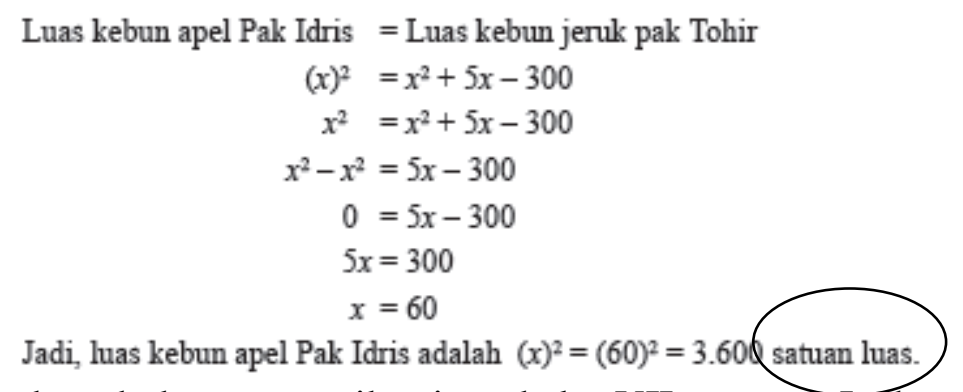

(Sumber : buku matematika siswa kelas VII semester I tahun 2013 revisi 2017 halaman 217)

pada permasalahan yang disajikan terlihat bahwa lahan berbentuk persegi yang memiliki satuan meter (hal ini terlihat dari besar satuan pada selisih panjang dan lebar yang menggunakan satuan meter). Namun pada solusi penyelesaian masalah yang disajikan menggunakan satuan luas. Maka perlu dilakukan revisi dengan menggunakan satuan luas yang sesuai dengan permasalahan yang disajikan pada 3.3

6) Penyajian konsep yang kurang lengkap

Operasi penjumlahan dan perkalian bentuk aljabar memiliki beberapa sifat, antara lain:

1. Sifat Komutatif

$a+b=b+a$

$a \times b=b \times a$

(Sudah ditunjukkan di depan)

(Sumber : buku matematika siswa kelas VII semester I tahun 2013

revisi 2017 halaman 195)

pada penyajian konsep tersebut, penulis menyebutkan (sudah ditunjukkan di depan), ini akan membuat pembaca (peserta didik) kebingungan mencari di halaman berapa yang dimaksud dari kata-kata tersebut. sebaiknya lebih detail menunjukkannya di halaman berapa konsep tersebut sudah dijelaskan penulis. 


\section{Kesimpulan}

Setelah melakukan analisis konten materi aljabar pada buku matematika siswa kelas VII peneliti menyimpulkan bahwa berdasarkan kelayakan isi materi aljabar, buku matematika siswa kelas VII semester I tahun 2013 revisi 2017 sudah baik untuk dijadikan buku ajar siswa. Pada materi aljabar tidak diketemukan kesalahan fakta, konsep, dan prinsip. Dalam penyajian materi sudah menerapkan pendekatan scientifik, adanya stimulasi berupa permasalahan awal, dan pemecahan masalah dalam bentuk kontekstual. Namun dalam kelayakan penyajian masih terdapat kesalahan dalam penyajian materi yang perlu diperbaiki agar kualitas buku ajar lebih baik lagi. Secara teori triadic didaktis, konten materi aljabar pada buku matematika kelas VII SMP sudah mengakomodasi Antisipasi Dedaktik Pedagogik (ADP) dan Hipotetikal Didaktis (HD). Disarankan bagi siswa dalam belajar ada baiknya belajar tidak hanya dari satu bukuteks saja, namun bisa juga dari sumber buku ajar yang lain yang sudah di nilai kelayakannya oleh Pusat Perbukuan dan juga sumber belajar dari internet dengan arahan dari guru.Disarankan bagi penulis buku teks matematika dalam menyajikan materiketika ada kesalahan untuk segera melakukan revisi sehingga sajian buku jauh lebih baik lagi.

\section{Daftar Pustaka}

Drijvers, P., Goddijn, A., \& Kindt, M.. (2010). Algebra education: Exploring topics and themes. In P. Drijvers, (Ed.), Secondary Algebra Education: Revisiting topics and themes and exploring the unknown (pp. 5-26). Rotterdam: Sense Publishers.

Ismunandar, D. (2019). Efektifitas Model Discovery Learning Di Kelas Viii Materi Relasi Dan Fungsi. PROSIDING Seminar Nasional Matematika Dan Pendidikan Matematika Unswagati, 2(1), 62-72.

Mulyono, Pudji. (2007). Kegiatan Penilaian Buku Teks. Bulletin BSNP, vol. II/No. 1/Januari, 2007.

Prastowo, Andi. (2011). Panduan Kreatif Membuat Bahan Ajar Inovatif. Yogyakarta: Diva Press.

Rizkianto dan Santoso. (2017). Analisis Buku Matematika Siswa SMP Kurikulum 2013. Jurnal "Mosharafa", Volume 6, Nomor 2, Mei 2017.

Wijaya, Aryadi. 2016. Aljabar: Tantangan beserta Pembelajarannya. JURNAL GANTANG Pendidikan Matematika FKIP - UMRAH Vol. 1 No. 1, Agustus 2016.

Purwita, Diana sari. (2016, November). Analisis kesalahan Buku Teks Matematika SMP/MTs Kelas VII Berdasarkan Objek Kajian Matematika. Prosiding Seminar Matematika dan Pendidikan Matematika FKIP UNS, hal 77-87, 16 November 2016.

Suryadi, Didi. (2013, Agustus). Didactical Design Research (DDR) dalam Pengembangan Pembelajaran Matematika. Prosiding Seminar Nasional Matematika dan Pendidikan Matematika STKIP Siliwangi Bandung, Volume 1, Tahun 2013.

Ghony dan Almanshur. (2012). Metodologi Penelitian Kualitatif. Yogyakarta: Arruzi Media. 